Reference

NBS

Publi .

cations

NBSIR $81-1640$

\title{
EFFECTIVE THERMAL CONDUCTIVITY OF A GLASS FIBERBLANKET STANDARD REFERENCE MATERIAL
}

David R. Smith

Jerome G. Hust

Lambert J. Van Poolen

Thermophysical Properties Division National Engineering Laboratory National Bureau of Standards Boulder, Colorado 80303

.456 



\section{NBSIR $81-1640$}

\section{EFFECTIVE THERMAL CONDUCTIVITY OF A GLASS \\ FIBERBLANKET STANDARD REFERENCE MATERIAL}

David R. Smith

Jerome G. Hust

Lambert J. Van Poolen

Thermophysical Properties Division

National Engineering Laboratory

National Bureau of Standards

Boulder, Colorado 80303

February 1981

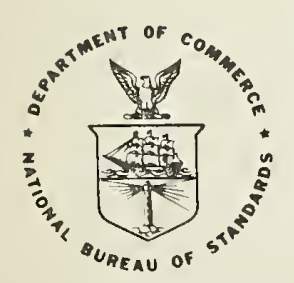

U.S. DEPARTMENT OF COMMERCE, Malcolm Baldridge, Secretary 


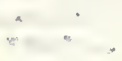

, 19 
CONTENTS

Introduction . . . . . . . . . . . . . . . . . . . Page

Apparatus and Specimen Characterization . . . . . . . . . . . 1

Results . . . . . . . . . . . . . . . . . . 3

References (Annotated Bibliography) . . . . . . . . . . . 12 



\section{Effective Thermal Conductivity \\ of a Glass Fiberblanket Standard Reference Material}

David R. Smith, Jerome G. Hust, and Lambert J. Van Poolen

This paper* describes the results of thermal conductivity measurements at temperatures from $84 \mathrm{~K}$ to $360 \mathrm{~K}$ on a glass fiberblanket insulation which is intended to be a Standard Reference Material (SRM). The measurements were performed in an atmosphere of dry nitrogen at a pressure near $84 \mathrm{kPa}(630 \mathrm{~mm} \mathrm{Hg})$. The results are analyzed and compared to literature data for similar material. An annotated bibliography of literature sources is included.

Key words: Glass fiberblanket; insulation; low temperature; standard reference material; thermal conductivity.

\section{Introduction}

As part of the National Bureau of Standards - Department of Energy Program to establish insulation Standard Reference Materials (SRM's), work is continuing on various candidate materials. The results on SRM 1450 (glass fiberboard) were reported earlier [1]. Results of measurements are reported here for a specimen of a glass fiberblanket insulation for specimen temperatures covering the range from $84 \mathrm{~K}$ to $360 \mathrm{~K}$, in an atmosphere of dry nitrogen gas at $84 \mathrm{kPa}$ (630 mm Hg), local atmospheric pressure.

\section{Apparatus and Specimen Characterization}

A commercial guarded-hot-plate thermal conductivity instrument was extensively modified [2] to permit efficient use of cryogenic or refrigerated coolants, to obtain greater stability of controlled temperatures, and to achieve

*This work was done for the Department of Energy, Oak Ridge Operation, Oak Ridge, TN 37830, under Interagency Agreement DoE No. DE-AI05-780R05965. 
lower imprecision and uncertainty of measurements. This apparatus was designed to measure heat transfer through a pair of specimens surrounding the horizontal hot plate in the typical double-sided guarded hot plate configuration (ASTM STM C-177).

The pair of specimens studied were disks of nominal $10 \mathrm{~cm}$ ( 4 in) diameter and $2.6 \mathrm{~cm}$ (1.0 in) thickness. They were cut from larger slabs measuring approximately $58 \mathrm{~cm}$ square as received from the National Bureau of Standards, Office of Standard Reference Materials stock. The pair was chosen on the basis of near equality of area densities $\left(0.0381 \mathrm{~g} / \mathrm{cm}^{2}\right.$ and $\left.0.0383 \mathrm{~g} / \mathrm{cm}^{2}\right)$. The thickness, $\Delta x$, of each specimen was determined during the conductivity measurement by three stainless steel spacer tubes positioned at three equidistant points around the perimeter of the guard material. The guard material was similar to that of the specimens with an inside diameter of $10 \mathrm{~cm}$ (4 in) and an outside diameter of $20 \mathrm{~cm}$ ( 8 in). The measured thickness was $2.59 \mathrm{~cm}$ and the resulting volume density was $14.75 \mathrm{~kg} / \mathrm{m}^{3}$. This thickness was corrected for thermal expansion of the spacers (less than 0.3 percent).

All hot plate/cold plate surfaces facing the specimens were black anodized aluminum. The cold surfaces were electrically heated, temperature-controlled plates, cooled by resistive thermal contacts with fluid-cooled copper plates; thus the cold surfaces of the specimens could be brought to a temperature near that of the coolant, or raised in temperature, as desired. The main heater (metered section) was a disk $10.16 \mathrm{~cm}$ in diameter separated by a $1.6 \mathrm{~mm}$ gap from the annular guard of $5.1 \mathrm{~cm}$ width. A concentric, cylindrical outer guard surrounded the stack of auxiliary heaters, specimens, and main heater. It established a temperature gradient approximating that of the stack about $2 \mathrm{~cm}$ away from the stack edge surfaces. 
Temperature controllers were used to regulate conditions in the inner and outer guards and to establish steady temperatures in the auxiliary heaters at the cold sides of the specimens. The offset signal for the inner-guard controller was developed by a 20-pair thermopile of type E thermocouples, with alternate junctions on opposite sides of the gap separating the main and innerguard heater plates.

Type $\mathrm{K}$ thermocouples ( 32 gauge) for determining temperatures of the specimen faces, positioned at the center and near the gap surrounding the main heater, were varnished to the surfaces of the hot and auxiliary plates over a length of $15 \mathrm{~cm}$. These thermocouples were also thermally tempered by means of $15 \mathrm{~cm}$ of wire wrapped and varnished to copper lugs attached to the periphery of the hot and auxiliary plates.

Type $\mathrm{K}$ thermocouple wire was calibrated using a calibrated platinum resistance thermometer and baths of liquid helium, liquid nitrogen, dry-ice-andalcohol, ice-water, room-temperature water, and boiling water. The departures from the standard tabular values* of emf vs. temperature were represented by a 3-term polynomial and a corrected calibration curve was formulated for the particular spools of thermocouple wire used.

The dc power, Q, for the main heater was obtained from a constant current power supply of better than 0.01 percent stability and accuracy. The power in the metered heater was found from the product of voltage drop, $V$, across the heater and the current, I, through the heater.

\section{Results}

Measurements of heat flow and of temperatures of the hot and cold surfaces were performed at mean temperatures from $95 \mathrm{~K}$ to $350 \mathrm{~K}$ with temperature

\footnotetext{
*Thermocouple Reference Tables based on IPTS-68, NBS Monograph 125, March, 1974.
} 
differences of about $25 \mathrm{~K}$ (gradient approximately $1 \mathrm{deg} / \mathrm{mm}$ ). The metered area $A_{m}$, was taken to be that contained within the $10.32 \mathrm{~cm}$ diameter circle including the main heater and one-half of the surrounding gap. The area through which the metered heat energy flows through the two matched specimens is $2 A_{m}$. This area was corrected for thermal expansion (less than 0.7 percent). The mean thermal conductivity, $\bar{k}$, was computed according to $\bar{k}=\frac{Q}{A} \frac{\Delta X}{\Delta T}=$ $\frac{V I}{2 A_{m}} \frac{\Delta X}{\left(T_{2}-T_{1}\right)}$, where $T_{2}$ and $T_{1}$ are the average hot and cold side temperatures, respectively. The resulting data set of values $\bar{k}, Q, T$, and $T_{2}$ were then functionally represented using a thermal conductivity integral (TCI) fitting technique* to yield the thermal conductivity as a continuous function of temperature over the range from the lowest value of $\mathrm{T}_{1}(84 \mathrm{~K}$ ) to the highest value of $\mathrm{T}_{2}(360 \mathrm{~K})$. This resulted in the values of the parameters, $A_{1}$ in the equation $k=\sum_{i=1}^{4} A_{i} T^{i}$. This technique is valid only to the extent that the mechanisms of heat transfer are conductive in nature (as opposed to direct radiation or convection). Deviations from this condition can be detected by searching for systematic trends in the deviations of the fitted data as a function of boundary conditions. This search will be conducted on more extensive data to be published later.

The values of $k$ vs. temperature obtained by means of this technique for the specimens are given in Table 1 and plotted in Fig. 1 (solid line). The values of $\bar{k}$ are also plotted in Fig. 1 (circles) at the mean temperature, $\overline{\mathrm{T}}$.

*Hust, J. G. and Lankford, A., Comments on the Measurement of Thermal Conductivity and Presentation of the Thermal Conductivity Integral Method, to be published. 
The fact that the mean values of thermal conductivity, $\bar{k}$, are consistent with the solid line for $k$ at $\bar{T}$ is indicative of the absence of appreciable nonconductive heat transfer mechanisms, i.e., direct radiation and convection. Deviations between $\bar{k}$ and $k$ at $\bar{T}$ can also be caused by non-linear behavior of $k$ vs. $T$ for just conductive heat transfer, but, in this case $k$ vs. $T$ is nearly linear. Table 2 gives the coefficients, $A_{i}$, and the range over which the fitted curve is valid. The TCI deviations, (TCI obs $\left.-\mathrm{TCI}_{\mathrm{Calc}}\right) \times 100 / \mathrm{TCI}_{\mathrm{obs}}$, between the data (obs) and the fitted (calc) curve are given in Fig. 2 as a function of mean temperature. The horizontal bars indicate the temperature range for each measurement and the range of the TCI. A three term polynomial fit showed large systematic deviations from the data but the four term polynomial exhibited mainly random deviations. The remaining small systematic deviations (approximately $\pm 1 / 2$ percent) were essentially unchanged from a four term to a seven term polynomial. Further analysis is planned on other data sets to ascertain if these systematic deviations reflect real behavior or experimental error. At about $320 \mathrm{~K}$ two triplets of points are shown in Fig. 2 which differ appreciably from the mean ( \pm 3 percent). These data are the result of running the apparatus in the single-sided mode, i.e., each triplet is a measure of only one or the other of the two specimens. Further analysis is required to determine if these deviations are caused by specimen variations or by differences in the apparatus configuration.

Other investigators [3-14] have reported similar trends in the dependence of $k$ on temperature for glass fiber insulations over a wide range of densities including our value. The characteristic differences of these insulations, 
such as binder or lubricant content, fiber size or atmospheric pressure actually present at each laboratory, are not known in great enough detail to permit definitive statements about the agreement or disagreement between results. Comparisons of literature data $[5,7,10,12,14]$ to our equation are illustrated in Fig. 3. The uncertainty of the present results is estimated to be \pm 1 percent. Research on this material is being continued to determine the effects of specimen density and fill gas species and pressure on the effective thermal conductivity. Other parameters such as thickness, plate emittance, and heat flow direction will also be examined to further elucidate the nature of the heat transfer mechanisms present. 


\section{Table 1}

Thermal conductivity of glass fiberblanket versus temperature based on the fitted results of the present investigation.

\begin{tabular}{|c|c|c|c|}
\hline $\mathrm{T}(\mathrm{K})$ & $\begin{array}{c}\mathrm{k} \\
(\mathrm{mW} / \mathrm{m} \mathrm{K})\end{array}$ & $T(K)$ & $\begin{array}{c}\mathrm{k} \\
(\mathrm{mW} / \mathrm{m} \mathrm{K})\end{array}$ \\
\hline 84 & 8.90 & 160 & 17.83 \\
\hline 85 & 9.01 & 170 & 19.10 \\
\hline 86 & 9.12 & 180 & 20.40 \\
\hline 87 & 9.24 & 190 & 21.74 \\
\hline 88 & 9.35 & 200 & 23.12 \\
\hline 89 & 9.46 & 210 & 24.56 \\
\hline 90 & 9.57 & 220 & 26.04 \\
\hline 91 & 9.68 & 230 & 27.59 \\
\hline 92 & 9.80 & 240 & 29.20 \\
\hline 93 & 9.91 & 250 & 30.89 \\
\hline 94 & 10.00 & 260 & 32.67 \\
\hline 95 & 10.14 & 270 & 34.53 \\
\hline 96 & 10.25 & 280 & 36.49 \\
\hline 97 & 10.36 & 290 & 38.57 \\
\hline 98 & 10.48 & 300 & 40.76 \\
\hline 99 & 10.59 & 310 & 43.08 \\
\hline 100 & 10.70 & 320 & 45.54 \\
\hline 110 & 11.85 & 330 & 48.15 \\
\hline 120 & 13.00 & 340 & 50.92 \\
\hline 130 & 14.18 & 350 & 53.87 \\
\hline 140 & 15.37 & 360 & 57.00 \\
\hline 150 & 16.59 & & \\
\hline
\end{tabular}


Table 2

$$
\begin{aligned}
\text { Coefficients of the Least-Squares Fit: } k=\sum_{i=1}^{4} A_{i} T^{i} \\
A_{1}=0.986120 \times 10^{-1} \\
A_{2}=0.121313 \times 10^{-3} \\
A_{3}=-0.562714 \times 10^{-6} \\
A_{4}=0.190726 \times 10^{-8}
\end{aligned}
$$

Range: $\quad 84 \mathrm{~K} \leq \mathrm{T} \leq 360 \mathrm{~K}$ 


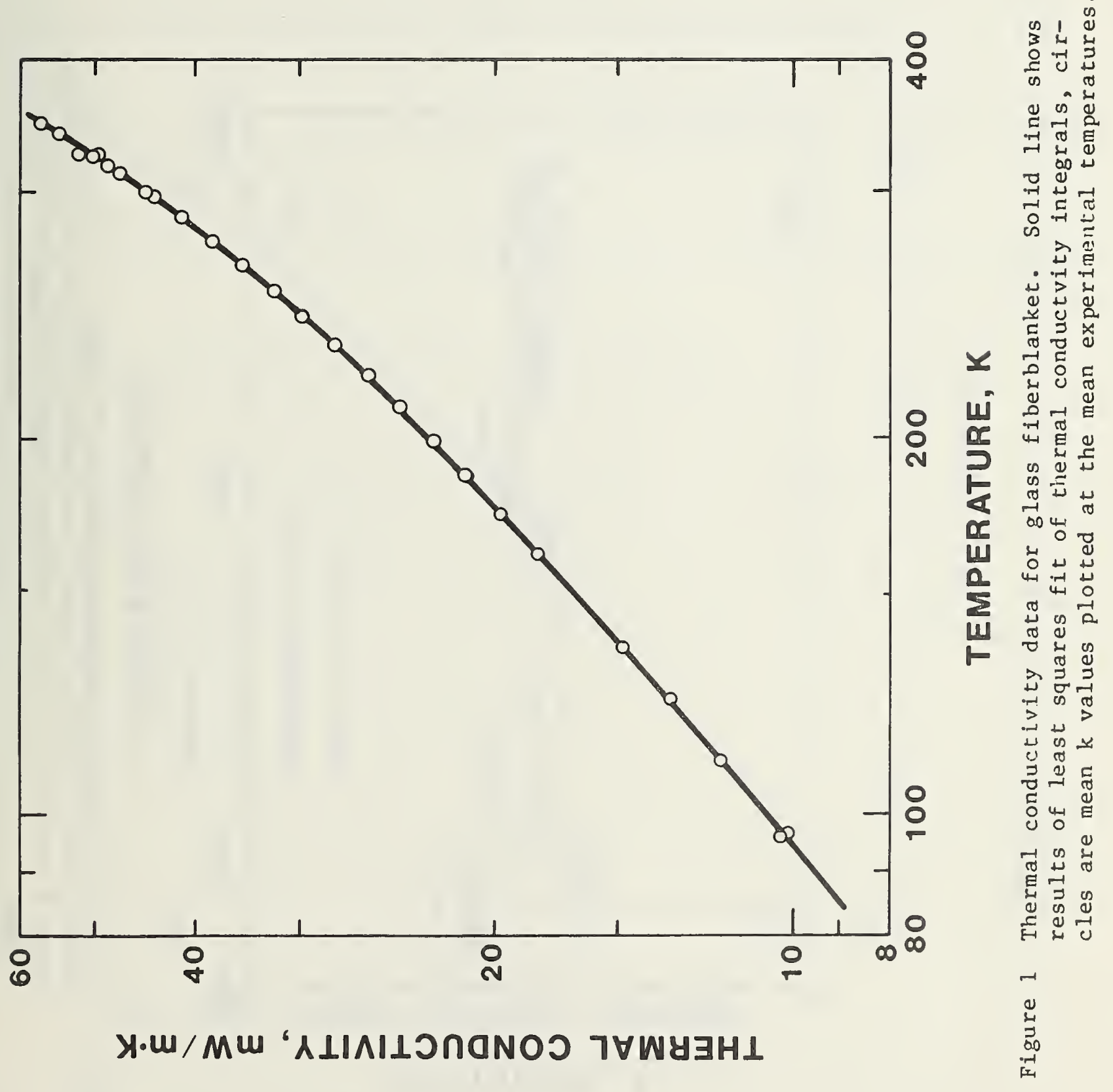




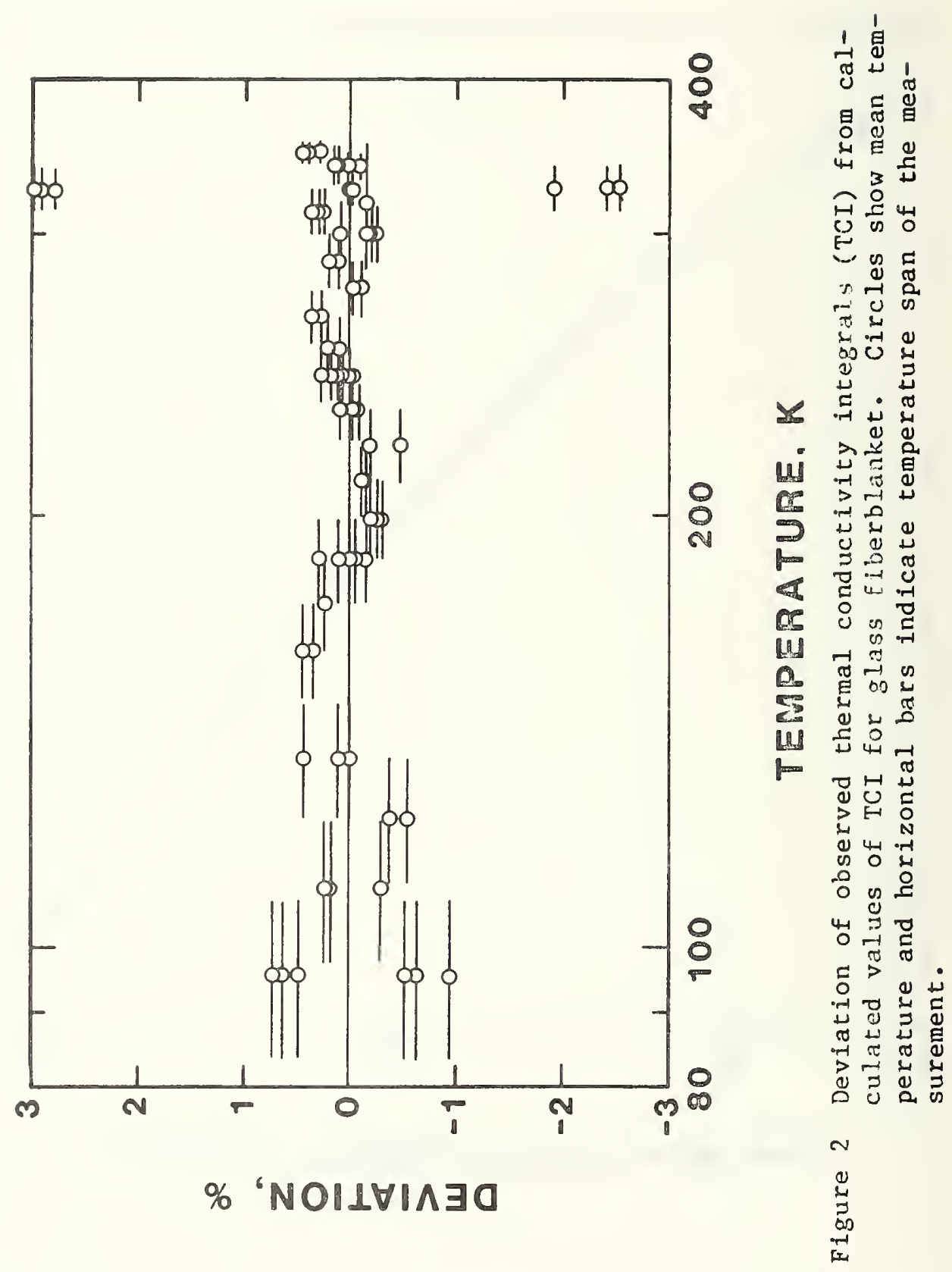




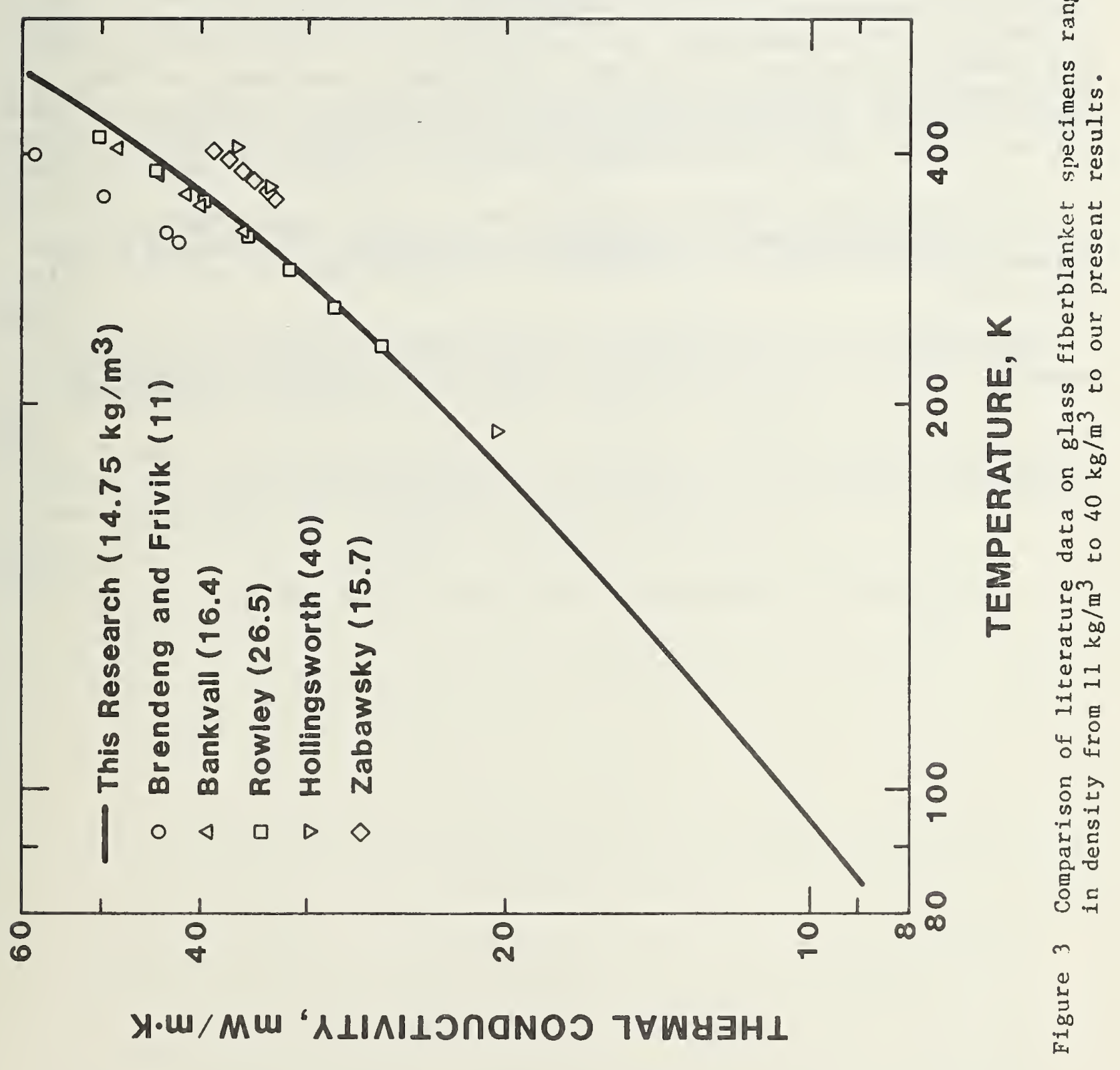


The references for this document and other papers of interest have been presented in the form of an annotated bibliography as an aid to the reader.

An extensive search has been made of the published literature relating to the effective thermal conductivity of fibrous glass insulation, in the range of densities characteristic of glass fiberblanket. Of special interest to the authors are studies relating to the dependence of $k$ on temperature, density, gas pressure and species of fill gas. The format, given below, for this bibliography is designed to present the conclusions of each paper in a concise manner. Not all papers fit the format in its entirety but the format includes all the relevant types of information found in the majority of papers studied.

It is found that authors' abstracts are not sufficiently detailed in describing specific types of specimen characterization, experinental or theoretical studies and conclusions; therefore abstracts have not been listed in this work.

The units shown in the annotated bibliography are those given in the original article. SI units have been added in parentheses for convenience. 


\section{REFERENCE}

AUTHOR, TITLE, CITATION

\section{ANNOTATION}

PURPOSE

SPECIMEN

a) Thickness; b) Density; c) Fill Gas Species/Pressure; d) Fiber Diameter; e) Bonding Agent; f) Other Characterization

APPARATUS

a) Type; b) Heater Dimensions: Overall/test; c) Plate Orientation or Radial Axis; d) Thermometry; e) Calibration; f) Remarks

THEORY

a) Physical/Mathematical Models Including Assumptions; b) Calculational Techniques; c) Results

DATA

a) Temperature Range/Gradient; b) Content of Tables, Figures, and Equations; c) Uncertainty/Imprecision; d) Disputable Corrections to Measurements by Authors; e) Errata (by Author or Reviewer)

ANALYSIS

a) Comparisons; b) Heat Transfer Mode Separations; c) Conclusions 
[1] Smith, D. R. and Hust, J. G., Measurement of Effective Thermal Conductivity of a Glass Fiberboard Standard Reference Material, to be published in

Cryogenics; sponsor report No. 773.30-80-2.

PURPOSE

To determine effective thermal conductivities of glass fiberboard materials over a temperature range from cryogenic levels to just above ambient and to develop this material as a standard reference.

APPARATUS

a) guarded hot plate; b) 8 inches $(20 \mathrm{~cm}) / 4$ inches $(10 \mathrm{~cm})$ dia.; c) horizontal; d) type $\mathrm{K}(\mathrm{Cr}-\mathrm{Al})$ thermocouples; e) calibration measurements agreed to within $1.5 \%$; f) apparatus operated over the range approx. 80 to $350 \mathrm{~K}$.

SPECIMEN

a) $2.59 \mathrm{~cm}$ (1 in); b) $123 \mathrm{~kg} / \mathrm{m}^{3} ;$ c) $\mathrm{N}_{2} /$ atmospheric

THEORY

a) $k$ vs $T$ (four term polynomial); b) thermal conductivity integral technique used to fit and calculate $k$ vs $T$; c) representation of data $\pm 0.4 \%$ over temperature range.

DATA

a) 87-340 K/1-4 K/mm; b) Table 1 and Figure 1 - k vs T, Figure 2 deviations from fit of thermal conductivity integrals, Figure $3-k$ vs $T$ comparisons with literature data; c) $\pm 1 \%$ overall

ANALYSIS

a) comparison to literature data

[2] Smith, D. R., Hust, J. G., and Van Poolen, L. J., A Guarded-Hot-Plate Apparatus for Measuring Effective Thermal Conductivity of Insulations Between $80 \mathrm{~K}$ and $350 \mathrm{~K}$ (to be published as an NBSIR).

PURPOSE

To describe in detail the modifications made to a commercial guarded hot plate apparatus for use as a certification device.

APPARATUS

a) guarded hot plate; b) 8 inches $(20 \mathrm{~cm}) / 4$ inches $(10 \mathrm{~cm})$ dia.; c) horizontal; d) type $\mathrm{K}$ ( $\mathrm{Cr}-\mathrm{Al}$ ) thermocouples; e) calibration measurements agreed to within $1.5 \%$; f) apparatus operated over the range approx. 80 to $350 \mathrm{~K}$ 
[3] Allcut, E. A., An Analysis of Heat Transfer Through Thermal Insulating Materials, General Discussion on Heat Transfer, Sep. 1951, IME/ASME pp. 232235, 486-487 (Inst. Mech. Eng., London, 1951)

PURPOSE

Study influence of radiation and convection on heat transfer in fibrous insulation.

SPECIMEN

b) 1.25 to $3.51 \mathrm{~b} / \mathrm{cu} \mathrm{ft}\left(20\right.$ to $\left.56 \mathrm{~kg} / \mathrm{m}^{3}\right)$; c) air/0.4 to $80 \mathrm{in} \mathrm{Hg}(1.3$ to $270 \mathrm{kPa}$ )

APPARATUS

a) guarded hot plate; b) 8 inches $(20 \mathrm{~cm})$; f) enclosed in pressure-vacuum tank

DATA

a) 34 to $96^{\circ} \mathrm{F} / 34$ to $62^{\circ} \mathrm{F}$ difference ( 1 to $36^{\circ} \mathrm{C} / 19$ to $34^{\circ} \mathrm{C}$ difference)

b) Table 1: $k$ vs density for glass wool batts

2: $k$ vs $p$ for air cell

3,4,5: $\mathrm{k}$ vs $\mathrm{p}$ vs $\mathrm{T}$ vs density for glass wool batts

6: \% of total heat transmitted by convection

Figure 1: $k$ vs density for various materials including mineral wool

2: k vs cell size for Styrofoam

3: $k$ vs $p$ for various materials

4: $k$ vs $p$ vs density for glass wool

5: $(\mathrm{p} / \mathrm{k})$ vs $\mathrm{p}$ for glass wool

6,8: convection vs $p$, and density for glass wool.

ANALYSIS

b) radiation effect is negligible in glass wool blankets exceeding $21 \mathrm{~b} / \mathrm{cu}$ $\mathrm{ft}\left(32 \mathrm{~kg} / \mathrm{m}^{3}\right)$ density; c) In cellular or granulated materials, $\mathrm{k}$ varies almost directly with cell size. 
[4] Allcut, E. A., Properties of Heat Insulating Materials, The Engineering Journal, 514-520 (Nov. 1941)

PURPOSE

A discussion of the character of heat insulating material, the difficulties in determining their relative value experimentally, the effect of air spaces and surface resistance and the possibility of saving fuel by taking advantage of solar radiation and heat stored in the structure of the building itself. An appendix describes a microscopic examination of a number of insulating materials.

SPECIMEN

a) 0.2 to 1.5 in ( 5 to $38 \mathrm{~mm}$ );

c) air/atmospheric;

e) $5.5 \mu \mathrm{m}$

b) 1.6 to $51 \mathrm{~b} / \mathrm{cu} \mathrm{ft}\left(26\right.$ to $\left.80 \mathrm{~kg} / \mathrm{m}^{3}\right)$;

APPARATUS

a) guarded Hot Plate; b) 8 in $(20 \mathrm{~cm})$ square; c) vertical

DATA

a) $90^{\circ} \mathrm{F} / 35$ to $200^{\circ} \mathrm{F} /$ in $\left(32^{\circ} \mathrm{C} / 8\right.$ to $\left.44^{\circ} \mathrm{C} / \mathrm{cm}\right)$

b) Table 1: $k$ vs thickness (density) for three blanket materials (one glass wool).

Table 2: Heat loss in insulated pipes.

Figure 1,2: Structure of different fiber boards.

3: Air leakage in rock wool

4: Air leakage in fiberboard, different densities.

6: $k$ vs air pressure for various materials

8: $k$ vs thickness

9: $k$ vs density

11: $k$ vs thickness

14: fiber-diameter distribution curve. 
[5] Bankvall, C., Heat Transfer in Fibrous Materials, J. of Testing and Evaluation, JTEVA, 1(3), 235-243 (May 1973).

\section{PURPOSE}

Mechanisms of heat transfer are calculated theoretically, then verified experimentally by measurements on glass fiber insulation in a specially constructed guarded hot plate apparatus. The author claims the theories give a complete and consistent explanation of the influence of the mechanisms of heat transfer on the effective thermal conductivity of fibrous material.

\section{SPECIMEN}

a) 0.5 to $5 \mathrm{~cm}$; b) 15 to $80 \mathrm{~kg} / \mathrm{m}^{3}$; c) air $/ 10^{-3}$ to $760 \mathrm{~mm} \mathrm{Hg}$ (0.1 to 100 $\mathrm{kPa})$; d) $5 \mu \mathrm{m}$; f) porosity, radiation coefficient.

\section{APPARATUS}

a) guarded hot plate, one-sided, rotatable; b) $35 \mathrm{~cm}$ diam; c) horizontal

\section{THEORY}

a) Fibers in layers at right angles to flow of heat; walls, fibers are "gray", non-transparent bodies; b) Two-phase open-pore model.

$$
\begin{aligned}
& \mathrm{k}_{\text {eff gas }}=\mathrm{k}_{\text {gas }} \frac{\mathrm{pL}_{\circ}}{\mathrm{pL}_{\circ}+\mathrm{ET}}, \mathrm{L}_{\circ}=\text { inter-fiber distance }=\pi \mathrm{D} / 4(1-\varepsilon) \\
& \mathrm{k}_{\text {eq. } \mathrm{fib}}=32(1-\varepsilon)^{2} \text { sol } / \pi\left(3+\frac{\pi}{4(1-\varepsilon)}\right) \\
& \mathrm{k}_{\text {eff rad }}=40 \mathrm{LT}_{\mathrm{m}}^{3} /\left(\beta^{-1}+\mathrm{L}_{\circ}\left(2 / \varepsilon_{\circ}-1\right) / \mathrm{d}\right)=40 \mathrm{~L}_{\circ} B \mathrm{~T}_{\mathrm{m}}^{3}
\end{aligned}
$$

DATA

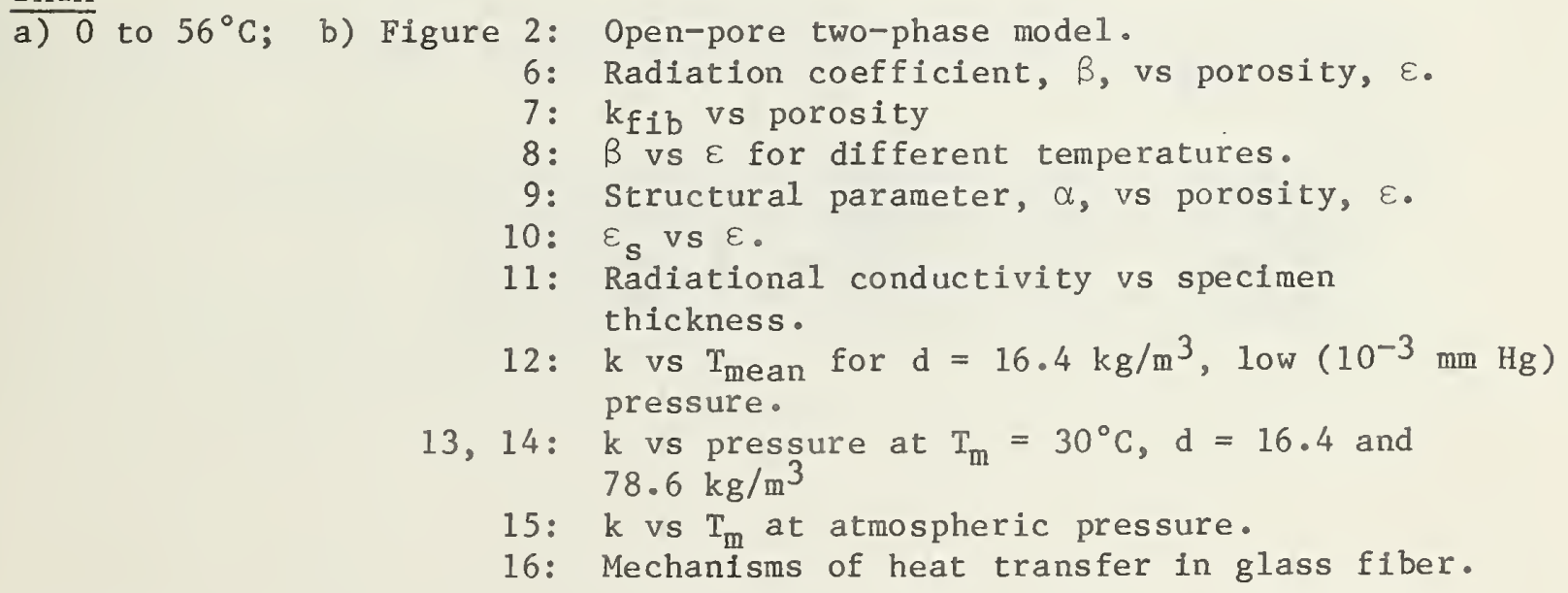

\section{ANALYSIS}

c) All mechanisms involved in transfer by gas must be considered, to be correct in estimating contribution by gas to $k_{e f f}$ d) Conduction in gas contributes largest part of $\mathrm{k}_{\mathrm{eff}}$ in range $15-80 \mathrm{~kg} / \mathrm{m}^{3}$. Radiation is of greatest importance at low density and leads to large $\mathrm{k}$ at low density. Conduction of solids is an important contribution at high density. Increasing temperature leads to larger $k$, especially at low density where radiation is important. 
[6] Bartoli, R. and Laine, P., Thermal Conductivity Measurements of Fiberglass Panels at Different Temperatures in Various Atmospheres, Supplement to Bull. of Int'1 Institute of Refrig. (Paris) Annexe 1956-2, pp. 233-240 (1956).

PURPOSE

Measurements of thermal conductivity of fiberglass panels in various gases, at different temperatures.

SPECIMEN
a) $5 \mathrm{~cm}$;
b) $33,88,120 \mathrm{~kg} / \mathrm{m}^{3}$;
c) air, $\mathrm{CO}_{2}, \mathrm{R}-12$;
d) $12 \times 10^{-6} \mathrm{~m}$;
e) none

\section{APPARATUS}

a) guarded hot plate; c) horizontal; d) copper-constantan thermocouples

DATA

a) -15 to $+15^{\circ} \mathrm{C} / 26$ to $66 \mathrm{~K} / \mathrm{cm}$

b) Figures $2,3,4: \mathrm{k}$ vs $\mathrm{T}$, several densities

$$
\begin{array}{rlrl}
\text { air: } & \mathrm{k}_{1}=(33.8+0.208 \mathrm{t}) \times 10-3 \mathrm{kCal} / \mathrm{m} \cdot \mathrm{h} \cdot{ }^{\circ} \mathrm{C}, & \mathrm{d}_{1}=33 \mathrm{~kg} / \mathrm{m}^{3} \\
\mathrm{k}_{2}=(26.8+0.145 \mathrm{t}) \times 10-3 & \mathrm{~d}_{2}=38 \mathrm{~kg} / \mathrm{m}^{3} \\
\mathrm{k}_{3}=(26.3+0.120 \mathrm{t}) \times 10-3 & \mathrm{~d}_{3}=120 \mathrm{~kg} / \mathrm{m}^{3} \\
\mathrm{CO}_{2}: \mathrm{k}_{1}=(23.6+0.185 \mathrm{t}) \times 10-3 & & \\
\mathrm{R}-12: & \mathrm{k}_{2}=(18.3+0.080 \mathrm{t}) \times 10-3 &
\end{array}
$$

\section{ANALYSIS}

a) At $0{ }^{\circ} \mathrm{C} \quad \frac{\mathrm{k}_{1}\left(\mathrm{CO}_{2}\right)}{\mathrm{k}_{1}(\mathrm{air})}=0.70, \frac{\mathrm{k}_{2}\left(\mathrm{CO}_{2}\right)}{\mathrm{k}_{2}(\mathrm{air})}=0.69, \frac{\mathrm{k}_{2}(\mathrm{R}-12)}{\mathrm{k}_{2}(\mathrm{air})}=0.45$

In good agreement with Verschoor and Greebler, $(0.71,0.71,0.47$, resp.) at $\mathrm{T}_{\mathrm{m}}=66^{\circ} \mathrm{C}$.

$$
\text { and } \begin{aligned}
\mathrm{k}_{1 \mathrm{~g}}(\mathrm{air}) & =(20.8+0.060 \mathrm{t}) \times 10^{-3} \mathrm{kCal} / \mathrm{m} \cdot \mathrm{h} \cdot{ }^{\circ} \mathrm{C} \approx \mathrm{k}_{2 \mathrm{~g}} \approx \mathrm{k} 3 \mathrm{~g} \\
\mathrm{k}_{\mathrm{lc}}(\mathrm{air}) & =(13.0+0.148 \mathrm{t}) \times 10^{-3} \mathrm{kCal} / \mathrm{m} \cdot \mathrm{h} \cdot{ }^{\circ} \mathrm{C} \\
\mathrm{k}_{2 \mathrm{c}}(\mathrm{air}) & =(5.55+0.084 \mathrm{t}) \times 10^{-3} \mathrm{kCal} / \mathrm{m} \cdot \mathrm{h} \cdot{ }^{\circ} \mathrm{C} \\
\mathrm{k}_{3 \mathrm{c}}(\mathrm{air}) & =(4.75+0.058 \mathrm{t}) \times 10^{-3} \mathrm{kCal} / \mathrm{m} \cdot \mathrm{h} \cdot{ }^{\circ} \mathrm{C}
\end{aligned}
$$


[7] Brendeng, E. and Frivik, P. E., New Development in Design of Equipment for Measuring Thermal Conductivity and Heat Flow, Heat Transmission Measurements in Thermal Insulations, ASTM-STP 544, pp. 147-166 (1974).

PURPOSE

This paper describes some of the recent developments in test equipment design and operation.

SPECIMEN

a) $10 \mathrm{~cm}$; b) $11,88 \mathrm{~kg} / \mathrm{m}^{3}$; c) air/atmospheric; f) temperature distribution; influences of convection, emissivity of plates.

APPARATUS

a) guarded hot plate; b) $0.4 \mathrm{~m} \mathrm{sq} \cdot$; c) horizontal; d) PRT and thermocouples; e) measured reference material calibrated at National Physical Laboratory (England)

DATA

a) -5 to $80^{\circ} \mathrm{C}$

b) Figure $8: \mathrm{k}$ vs $\mathrm{T}_{\mathrm{m}}$, glass wool and glass fiberboard, 11 and $88 \mathrm{~kg} / \mathrm{m}^{3}$ 9B: keff vs $\Delta \mathrm{T}$, glass wool 
[8] Christiansen, R. M. and Hollingsworth, M., Jr., The Performance of Glass Fiber Insulation Under High Vacuum, Advances in Cryogenic Engineering, 4 , 141-153 (Plenum, New York, 1960).

\section{PURPOSE}

Evaluate technique of partial removal of fill gas from fibrous insulation to improve thermal performance. Study effective thermal conductivity vs pressure, density and fiber diameter.

\section{SPECIMEN}

a) $0.2-1.8 \mathrm{in.}$ ( 5 to $45 \mathrm{~mm}$ ); b) $0.5-15 \mathrm{Ib} / \mathrm{cu} \mathrm{ft.} \mathrm{(8} \mathrm{to} 240 \mathrm{~kg} / \mathrm{m}^{3}$ ); c) air/2 10-4 mm $\mathrm{Hg}$ to 1 atm (0.03 to $100 \mathrm{kPa})$; d) 22,45,135, $480 \mathrm{micro}$ inches $(0.55,1.1,3.4,12 \mu \mathrm{m})$; e) heat felting or phenolic resin

\section{APPARATUS}
a) heat meter in bell jar;
b) 12 in $(30 \mathrm{~cm}) \mathrm{sq}$;
c) vertical;
d)
differential thermocouple;
e) samples of known conductivity

DATA

a) $75^{\circ} \mathrm{F} / 35$ to $200^{\circ} \mathrm{F} /$ in $\left(24^{\circ} \mathrm{C} / 8\right.$ to $\left.44^{\circ} \mathrm{C} / \mathrm{cm}\right)$;

b) For a density of $4 \mathrm{Ib} / \mathrm{ft}^{3}\left(64 \mathrm{~kg} / \mathrm{m}^{3}\right)$ :

$\mathrm{k}($ resid. gas $+\mathrm{sol})=0.0037,. \mathrm{k}(\mathrm{rad})=0.0065$ at $\mathrm{T}_{\mathrm{m}}=75^{\circ} \mathrm{F}\left(24^{\circ} \mathrm{C}\right)$

$\mathrm{k}($ resid. gas $+\mathrm{sol} \cdot)=0.0018, \mathrm{k}(\mathrm{rad})=0.0016$ at $\mathrm{T}_{\mathrm{m}}=-180^{\circ} \mathrm{F}$ $\left(-118^{\circ} \mathrm{C}\right)$

ANALYSIS

a) Figure 4: $k$ vs pressure (vs fiber diam. vs density)

6: k vs fiber diam. (vs density, pressure)

7: Importance of insulation in blocking radiation

9: component separations

c) For $0.1 \mathrm{~mm}<\mathrm{p}<100 \mathrm{~mm} \mathrm{Hg}(0.01$ to $13 \mathrm{kPa})$, finer fiber and higher density give lower $k$ At low density and high $p$, optimum fiber diam. is 50 $10^{-6}$ in $(130 \mu \mathrm{m})$. At low $\mathrm{p}$, higher density not harmful. Mean free path and average fiber spaçing control k.

Optimum density $81 \mathrm{~b} / \mathrm{cu}$ ft $\left(130 \mathrm{~kg} / \mathrm{m}^{3}\right)$ at vacuum, $41 \mathrm{~b} / \mathrm{cu}$ ft $(60$ $\mathrm{kg} / \mathrm{m}^{3}$ ) at atmospheric pressure.

Existence of optimum fiber diameter, predicted by Larkin, confirmed, because at very low $\mathrm{p}, \mathrm{k}$ (res) is due to radiation and solid conduction. When fiber insulation is present at moderately low pressure $(0.1 \mathrm{~mm}, 10$ $\mathrm{Pa}$ ) $\mathrm{k}$ is as low as in high vacuum. Fiber insulation necessary to block radiation between surfaces. 
[9] Fournier, D. and Klarsfeld, S., Some recent Experimental Data on Glass Fiber Insulating Materials and Their Use for a Reliable Design of Insulation at Low Temperatures, Heat Transmission Measurements in Thermal Insulations, ASTM STP 544, American Society for Testing and Materials, 223-242 (1974).

\section{PURPOSE}

To give theoretical criteria for onset of natural convection in open-pore thermal insulators; measure $k$; measure permeability to flow of air; guide wall design in minimization of heat transfer.

\section{SPECIMEN}
a) 24-28 $\mathrm{mm}$;
b) $8-135 \mathrm{~kg} / \mathrm{m}^{3}$;
c) air/atmospheric;
d) $2.5,3,6,12 \mu \mathrm{m}$;

f) TEL glass fiber, porosity

$.93-.997$

\section{APPARATUS}

a) guarded hot plate; b) 8 in $(20 \mathrm{~cm}) / 4$ in $(10 \mathrm{~cm})$ dia; c) horizontal;

d) thermocouple

\section{THEORY}

a) right-angle parallelepipedic, tight volume insulating cell, horizontal/vertical orientations; onset of convective motion-filtration Rayleigh Number $>40$, for horizontal cells and Rayleigh Number/Aspect Ratio $>4$ in vertical cells; c)predict natural convection increases in low temperature ranges

DATA

a) $123-300 \mathrm{~K}, 20-70 \mathrm{~K} /$ in ( 8 to $28 \mathrm{~K} / \mathrm{cm}$ );

b) Figure 4: k vs density - fineness ratio as parameter

5-6: permeability vs density - fineness ratio as parameter

7-9: $\mathrm{k}$ vs $\mathrm{T}_{\text {mean, density as parameter }}$

other data relating to permeability and convection

\section{ANALYSIS}

a) to measurements in a different apparatus - $3 \%$ agreement; b) study made of natural convection effect; c) for $T<200 \mathrm{~K}$, density has little influence on $k$ - this is also true of fineness index; TEL glass fiber material for $k$ at temperatures below $198 \mathrm{~K}$ behaves similar to cellular plastics and perlite; there are minimum acceptable densities for various thicknesses, temperatures, and fineness ratios to prevent convection 
[10] Hollingsworth, M., Jr., An Apparatus for Thermal Conductivity at Cryogenic Temperatures Using a Heat Flow Meter, ASTM STP 411: Thermal Conductivity

Measurements of Insulating Materials at Cryogenic Temperatures, 43-51, 1967.

PURPOSE

Evaluate a heat-flow-meter apparatus capable of measuring thermal conductivity of flat insulation specimens at cryogenic temperatures

SPECIMEN

a) 0.5 to 1 inch $\left(1.2\right.$ to $2.5 \mathrm{~cm}$ ); b) $0.85-3.21 \mathrm{bm} / \mathrm{ft}^{3}$ ( 14 to 51 $\left.\mathrm{kg} / \mathrm{m}^{3}\right)$; c) air, atmospheric

APPARATUS

a) heat meter in bell jar; b) $12 \times 12(30 \mathrm{~cm})$ in sq/6 66 in (15 cm) sq;

c) vertical;

d) copper-constantan thermocouples

DATA

a) -125 to $120^{\circ} \mathrm{F}\left(-87\right.$ to $\left.49^{\circ} \mathrm{C}\right)$; b) Figure 4 , k vs $T_{\text {mean }}$ for 4 different densities

ANALYSIS

a) results compared with guarded hot plate data from $100-300^{\circ} \mathrm{F}$ (38 $\left.149^{\circ} \mathrm{C}\right)$; c) apparent good agreement with guarded hot plate data but no accuracy information given because no direct comparisons can be made, i.e., at exactly the same test conditions 
[11] Lander, R. M., Gas is an Important Factor in the Thermal Conductivity of

Most Insulating Materials, Part II, ASHVE Transactions, 151-168 (1955).

\section{PURPOSE}

Describes investigation of the reduction in thermal conductivity of common insulating materials by replacing air with gases of larger molecular weight or fill gas.

\section{SPECIMEN}

a) 1 in $(25 \mathrm{~mm})$; b) $0.58,0.78,1.94,3.801 \mathrm{~b} / \mathrm{ft}^{3}(9,12,31,61$ $\left.\mathrm{kg} / \mathrm{m}^{3}\right)$; c) Air, $\mathrm{Co}_{2}, \mathrm{R}-12 / 0.1 \mu \mathrm{m}$ of $\mathrm{Hg}$ to 1 atm $(0.01$ to $100 \mathrm{kPa})$

\section{APPARATUS}

a) guarded hot plate; b) 12 in $(30 \mathrm{~cm})$ square; c) vertical; d) thermocouples

\section{DATA}

a) $100^{\circ} \mathrm{F}$ mean, $50^{\circ} \mathrm{F} /$ in $\left(38^{\circ} \mathrm{C}, 11^{\circ} \mathrm{C} / \mathrm{cm}\right)$

b) Table 1: $k$ vs fill gas; $k$ (air) vs $p ; \%$ reduction in heat transfer due to gas substitutions

2: $k$ vs $p$ for air, $\mathrm{CO}_{2} \mathrm{R}-12$

3: $k$ vs \% mixture of $\left(\mathrm{CO}_{2}, \mathrm{R}-12\right)$ with air

4: $k$ vs $T$ for various gases/densities

5: Calculated Different Modes of Heat Transfer for three densities, three gases, vs $T$.

Figure 7: $k$ vs $T$ for glass wool in air, $\mathrm{CO}_{2}, \mathrm{R}-12$ for varying insulation densities

9: Gas transferred heat vs $\mathrm{T}$ for various $\mathrm{fill}$ gases

11: Heat transferred by radiation/conduction vs density for various $T^{\prime} \mathrm{s}$.

\section{ANALYSIS}

b) Fiber conduction/gas transferred heat (conduction)/radiation

c) Major mode of heat transfer is by the fill gas,

18 to $31 \%$ reduction in $\mathrm{k}$ if $\mathrm{CO}_{2}$ replaces air,

28 to $56 \%$ reduction in $k$ if $\mathrm{R}-12\left(\mathrm{CF}_{2} \mathrm{Cl}_{2}\right)$ replaces air,

Conductivity of glass wool is decreased for increasing density (amount of decrease independent of fill gas).

For practical insulation, radiation is an important mode of heat transfer - conduction through fibers is negligible Convection not important except for large volumes of low density insulation. 
[12] Rowley, F. B., Jordan, R. C., and Lander, R. M•, Thermal Conductivity of Insulating Materials at Low Mean Temperatures, Refrigerating Engineering ( $\mathrm{J}$. of ASRE), Vo1. 50, No. 6, 541-4, (Dec., 1945).

\section{PURPOSE}

An apparatus was built to measure thermal conductivity of common insulating materials at low temperatures

SPECIMEN

a) 0,75 to 1 inch $\left(1.9\right.$ to $2.5 \mathrm{~cm}$ ); b) $1.65-15.71 \mathrm{bm} / \mathrm{ft}^{3}$ (26 to 251 $\left.\mathrm{kg} / \mathrm{m}^{3}\right)$; b) air, atmospheric

APPARATUS

a) guarded hot plate;

b) $12 \times 12$ in $(30 \mathrm{~cm}) \mathrm{sq} / 8 \times 8$ in $(20 \mathrm{~cm}) \mathrm{sq}$;

c) vertical

DATA

a) -60 to $90^{\circ} \mathrm{F}\left(-51\right.$ to $\left.32^{\circ} \mathrm{C}\right)$; b) Table 1 : for 10 materials of varying density, $k$ vs $T_{\text {mean; }}$ Figs. $3-10 \mathrm{k}$ vs $\mathrm{T}_{\text {mean }}$ at a given density

ANALYSIS

c) Dropping $\mathrm{T}_{\text {mean, }}$ drops $\mathrm{k}$ with the higher density materials having the lower percentage drop 
[13] Wilson, F. C., Evacuated and Gas-filled Insulation Systems, Refrig. Eng., pp. 57-60, 102, (Apr. 1957).

PURPOSE

Study effective thermal conductivity in fibrous glass insulation vs species of fill gas, gas pressure, fiber diameter.

\section{SPECIMEN}

b) $1,2,9.7,10.91 \mathrm{~b} / \mathrm{cu}$ ft $\left(16,32,155,174 \mathrm{~kg} / \mathrm{m} ;\right.$ c) $\mathrm{R}-12, \mathrm{CO}_{2}, \mathrm{Ne}$ at atmospheric, air at $10 \mathrm{\mu m} \mathrm{Hg}$ to 1 atm $\left(10^{-3}\right.$ to $\left.100 \mathrm{kPa}\right)$; d) $27,150,350,500,600$, micro-inches $(0.68,4,9,12,15 \mu \mathrm{m})$; e) none; f) two gas mixtures: $\mathrm{H}_{2}-\mathrm{CO}_{2}$ and $\mathrm{R}-12-\mathrm{air}$.

APPARATUS

a) guarded hot plate; b) specimen in thin bags enclosing fill gas, or apparatus in steel vacuum tank

DATA

a) $75-150^{\circ} \mathrm{C}$;

b) Tables I-III: $k$ vs fill gas species at three mean temperatures, four fiber diameters and four densities:

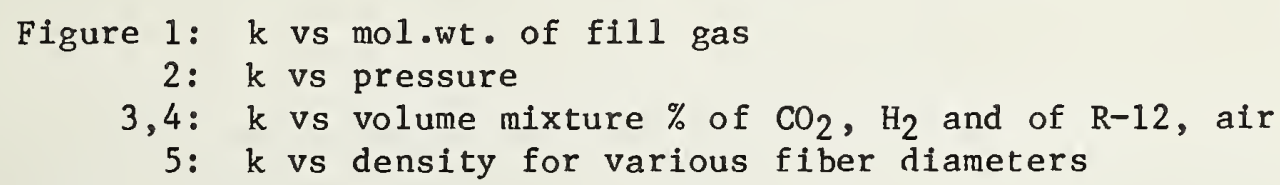

ANALYSIS

c) to reduce thermal conductivity by choice of fill gas, use any mol.wt. $\geq 50$,

$\mathrm{k}$ is greater for coarser fibers,

$k$ is at residual level for $p<0.01 \mathrm{~mm}$ of $\mathrm{Hg}$ ( $1 \mathrm{~Pa}$ ),

$k$ increases less than linearly from value for high-mol.wt. fill gas when diluted (air),

Optimum density for 150 micro-inch ( $4 \mu \mathrm{m}$ ) fiber is $2.51 \mathrm{~b} / \mathrm{cu} \mathrm{ft}$ (40 $\left.\mathrm{kg} / \mathrm{m}^{3}\right)$. 
[14] Zabawsky, Z., An Improved Guarded Hot Plate Thermal Conductivity Apparatus with Automatic Controls, ASTM Symposium on Thermal Conductivity Measurements, STP No. 217, 3-17 (1957).

\section{PURPOSE}

To describe an apparatus constructed according to ASTM Standard C177-45 but with additional changes to allow measurement of $k$ within $1 \%$ of values determined by the National Bureau of Standards.

SPECIMEN

a) 0.5 to 1.5 in ( 13 to $38 \mathrm{~mm}$ ); b) $9.6,15.7$, and $68.2 \mathrm{~kg} / \mathrm{m}^{3}$

APPARATUS

a) guarded hot plate; c) horizontal; d) thermocouples; f) heater to guard $+0.004^{\circ} \mathrm{F}\left(0.002^{\circ} \mathrm{C}\right)$, cold plate control $\pm 0.05^{\circ} \mathrm{F}\left(0.03^{\circ} \mathrm{C}\right)$, reproducibility $\pm 0.5 \%$.

DATA

a) $60-110^{\circ} \mathrm{F}$ (16 to $43^{\circ} \mathrm{C}$ ); b) Fig. $14 \mathrm{k}$ vs $\mathrm{T}$ for three fiberglass materials 
NBS-114A (REV. $2-8 \mathrm{C}$ )

U.S. DEPT. OF COMM.

BIBLIOGRAPHIC DATA

SHEET (See instructions)
1. PUBLICATION OR
REPORT NO.

NBSIR $80-1640$
2. Performing Organ. Report No.

,

3. Publication Date

February 1981

4. TITLE AND SUBTITLE

Effective Thermal Conductivity of a Glass Fiberblanket

Standard Reference Material

5. AUTHOR(S)

D. R. Smith, J. G. Hust, and L. J. Van Poolen

6. PERFORMING ORGANIZATION (If joint or other than NBS, see instructions)

7. Contract/Grant No.

NATIONAL BUREAU OF STANDARDS

DEPARTMENT OF COMMERCE

WASHINGTON, D.C. 20234

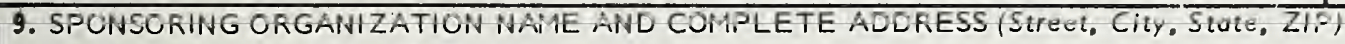

Department of Energy

Oak Ridge Operation

Oak Ridge, Tennessee 37830

(Under Interagency Agreement DoE No. DE-AI05-780R05965)

10. SUPPLEMENTARY NOTES

[ Document describes a computer program; SF-185, FIPS Software Summary, is attached.

11. ABSTRACT (A 200-word or less factual summary of most significant information. If document includes a significant bibliography or literature survey. mention it here)

This paper describes the results of thermal conductivity measurements at temperatures from $84 \mathrm{~K}$ to $360 \mathrm{~K}$ on a glass fiberblanket insulation which is intended to be a Standard Reference Material (SRM). The measurements were performed in an atmosphere of dry nitrogen at a pressure near $84 \mathrm{kPa}$ $(630 \mathrm{~mm} \mathrm{Hg})$. The results are analyzed and compared to literature data for similar material. An annotated bibliography of literature sources is

included.

12. KEY WORDS (Six to twelve entries; alphabetical order; capitalize only proper names; and separate key words by semicolons) Glass fiberblanket; insulation; low temperature; standard reference material; thermal conductivity.

\section{AVAILABILITY}

X] Unlimited

$\square$ For Official Distribution. Do Not Release to NTIS

$\square$ Order From Superintendent of Documents, U.S. Government Printing Office, Washington, D.C. 20402.

XX Order From National Technical Information Service (NTIS), Springfield, VA. 2216I
14. NO. OF PRINTED PAGES

$$
32
$$

15. Price

$\$ 6.50$ 


